\title{
Dietary Protein Intake, Breast Feeding and Growth in Human Milk Fed Preterm Infants
}

\author{
Emma Tonkin ${ }^{1}$ (D), Jacqueline Miller 1,2 (i), Maria Makrides 2,3 (i), Andrew J. McPhee 2,4, \\ Scott A. Morris ${ }^{5}$, Robert A. Gibson ${ }^{2,6}$ and Carmel T. Collins ${ }^{2,3, *}$ \\ 1 Nutrition and Dietetics, College of Nursing and Health Sciences, Flinders University, Adelaide, SA 5001, \\ Australia; emma.tonkin@flinders.edu.au (E.T.); jacqueline.miller@sahmri.com (J.M.) \\ 2 Healthy Mothers, Babies and Children, South Australian Health and Medical Research Institute, Adelaide, \\ SA 5001, Australia; maria.makrides@sahmri.com (M.M.); andrew.mcphee@sa.gov.au (A.J.M.); \\ robert.gibson@adelaide.edu.au (R.A.G.) \\ 3 Adelaide Medical School, Discipline of Paediatrics, The University of Adelaide, Adelaide, SA 5001, Australia \\ 4 Neonatal Medicine, Women's and Children's Hospital, Adelaide, SA 5006, Australia \\ 5 Centre for Perinatal Medicine Flinders Medical Centre and School of Medicine, Flinders University, \\ Adelaide, SA 5042, Australia; scott.morris@sa.gov.au \\ 6 School of Agriculture, Food and Wine, The University of Adelaide, Adelaide, SA 5064, Australia \\ * Correspondence: carmel.collins@sahmri.com; Tel.: +61-8-8128-4409
}

Received: 6 April 2018; Accepted: 5 June 2018; Published: 7 June 2018

\begin{abstract}
Protein intakes of preterm infants are frequently below recommendations, but few studies report accurate intakes due to the difficulty of analysing human milk clinically. This observational analysis from a randomised trial of infants born $<31$ weeks' gestation, investigating two levels of protein fortification, reports protein intakes compared with requirements and determines the association of direct breastfeeding on growth. Ninety-two infants (median gestational age 28 weeks, Interquartile range (IQR) 26-29; mean birth weight $1040 \mathrm{~g}$, SD $300 \mathrm{~g}$ ) were studied. Infants born weighing $<1000 \mathrm{~g}$ were underfed protein compared with recommendations (median (IQR) intake of $3.0(2.0-3.7) \mathrm{g} / \mathrm{kg} /$ day in week 2 versus recommendation of $4-4.5 \mathrm{~g} / \mathrm{kg} /$ day), while those born weighing $\geq 1000 \mathrm{~g}$ met recommended protein intakes after the first week of life (median (IQR) intake of $3.7(3.0-4.0) \mathrm{g} / \mathrm{kg} /$ day in week 2 versus recommendation of 3.5-4.5 g/ kg/day). A moderate, negative correlation between the mean number of breast feeds and change in rate of weight gain $(r=-0.37, p=0.001)$ was found. Protein intakes of infants $<1000 \mathrm{~g}$ did not meet recommendations and all infants were underfed protein and energy in the first week of life. Current protein fortification is inadequate for infants born $<1000 \mathrm{~g}$. Exploratory analysis showed faltering rate weight gain associated with increasing number of breast feeds and these results warrant confirmation.
\end{abstract}

Keywords: breast feeding; dietary proteins; enteral nutrition; infant-premature; milk-human; weight gain

\section{Introduction}

The importance of adequate nutrition for preterm infants to support growth is well known [1]. Better neurodevelopmental outcomes at 18 months are associated with improved rate of growth before, rather than after, 40 weeks post-menstrual age (PMA) [2,3] and the use of human milk [4]. Thus, optimising dietary management and nutrient intake to ensure quality postnatal growth before term equivalent is important [5]. Feeding preterm infants is complex, and evidence from contemporary dietary intake studies on preterm infants born $<1500 \mathrm{~g}$, fed with fortified human milk, suggest infants currently have energy intakes above recommendations [6,7] while receiving inadequate protein in the early weeks of life [7-10]. Yet few studies report accurate macronutrient intakes of human milk (HM) 
fed infants due to difficulty in assessing HM composition in the clinical setting [6,8]. Assumed values for the protein concentration of HM used in the literature vary from $12 \mathrm{~g} / \mathrm{L}$ [9] to $15 \mathrm{~g} / \mathrm{L}$ [8]. Thus studies comparing actual with assumed protein intakes can either under [8] or overestimate [9] actual intakes highlighting the importance of measuring HM composition.

HM is widely acknowledged as the preferred feed for preterm infants' due to the immunological and nutritional benefits it confers [1,11,12]. However, HM requires fortification with protein, energy and micronutrients for infants born weighing $<1500 \mathrm{~g}$ to meet nutritional requirements [13] with current typical commercial fortifiers providing an additional 0.8 to $1.8 \mathrm{~g}$ protein per $100 \mathrm{~mL}$ of expressed breast milk (EBM). The optimal level of protein fortification is still under debate but there is some evidence that protein fortification regimes are inadequate to meet protein requirements $[8,14,15]$. Transitioning from tube-feeding to oral intake via direct breast feeding is an important step in preparing preterm infants for discharge [16]. However, the potential to fortify feeds with key nutrients is lost with the introduction of direct breast feeds. While preterm infants post-discharge have been shown to adjust their volume of intake depending on calorie density [17] a Cochrane review of ad libitum feeding versus scheduled feeding for preterm infants during the neonatal admission has shown a lower nutrient intake in those infants on the ad lib regime [18]. Hence, human milk fed infants, while receiving many of the advantages that human milk confers, may have lower protein intakes during their neonatal admission because of the dual effect of inadequate fortification regimes during tube feeding and cessation of this fortification once direct breastfeeding commences. Additionally, mothers with inadequate breast milk supply will rely more on preterm formula during this interval and may therefore have higher protein intakes.

A randomised trial evaluating the effect of a higher protein human milk fortifier (HMF) compared with standard protein, on preterm infant growth included analysis of mothers' HM samples for protein and fat content, thus accurate enteral protein intakes for all infants could be reported [19]. Although all mothers involved in the trial intended to exclusively supply HM, a pragmatic approach was taken to feeding preterm formula when mother's milk was insufficient. This is reflective of the mixed-feeding approach in clinical practice typical of the time, when few centres in Australia had human milk banks. Additionally, infants who developed serious illness, such as lung disease, were not excluded from participation. These data therefore provide the basis for the present study in which we aimed to: (1) describe actual protein and energy intakes of human milk fed preterm infants fed 2 different protein levels during their neonatal admission, stratified by birth weight ( $<1000 \mathrm{~g}$ and $\geq 1000 \mathrm{~g}$ ) (2) to compare these with current recommended intakes and (3) to determine the association between direct breast feeding and growth.

\section{Materials and Methods}

\subsection{Study Design and Participants}

The original randomised trial [19] investigated the effect of a higher protein HMF on growth in preterm infants with the primary outcome of length gain. Participants were recruited from the Women's and Children's Hospital and Flinders Medical Centre (Adelaide, Australia) between October 2006 and June 2008. Study start was the date the study fortifier was introduced, and infants were followed until the estimated due date or discharge (whichever came first). Infants were included if they were born at $<31$ weeks' gestation and their mother intended to supply human milk. Exclusion criteria included: major congenital or chromosomal abnormality, infants where extra dietary protein was contraindicated (e.g., phenylketonuria), low maternal milk supply and continuation of expressing HM uncertain and likely transfer to a hospital which would make follow up difficult. Ninety-two infants were enrolled in the original study and all were included in the present study. The details of recruitment, randomisation and blinding are reported elsewhere [19]. Ethics approval was granted by the human research ethics committee of the Children, Youth and Women's Health Service (REC 1774) and Flinders Medical Centre (CDTC 187/067). 


\subsection{Management of Feeds}

Infants were randomly assigned to receive either the trial HMF (higher protein, containing $1.4 \mathrm{~g}$ protein added to $100 \mathrm{~mL}$ of $\mathrm{HM}$ ) or control HMF (standard protein, containing $1 \mathrm{~g}$ protein added to $100 \mathrm{~mL}$ of HM). Energy was kept constant $(17 \mathrm{kcal} / 100 \mathrm{~mL})$ by the addition of carbohydrate to the standard protein fortifier. The composition of both HMFs are reported elsewhere [19]. Infants received parenteral nutrition for a short period immediately post-birth. When HM was unavailable due to insufficient supply, a standard preterm formula containing $2.4 \mathrm{~g}$ protein and $80 \mathrm{kcal}$ per $100 \mathrm{~mL}$ was provided. A standardised enteral nutrition management protocol was used in both units as follows: Enteral feeds were commenced with unfortified expressed HM or if unavailable, preterm formula as soon as the infant was stable, aiming for day 1-2. Feeds were commenced at $5-10 \mathrm{~mL} / \mathrm{kg} /$ day, advancing by $10-20 \mathrm{~mL} / \mathrm{kg} /$ day as tolerated to a final volume of $160-180 \mathrm{~mL} / \mathrm{kg} /$ day. HM fortification commenced when enteral intake reached $\geq 80 \mathrm{~mL} / \mathrm{kg} /$ day.

\subsection{Dietary Intake}

Enteral intake data were collected prospectively from detailed clinical fluid balance charts. This included volume and caloric density of HM and formula, supplements provided and number of direct breast feeds. Enteral intake before enrolment and all parenteral intakes were collected retrospectively using fluid balance charts and drug orders. An aliquot of the infant's pooled $24 \mathrm{~h}$ period unfortified EBM was analysed weekly and was assumed representative of the HM composition for \pm 3 days around the collection date. The sample comprised freshly expressed HM and/or thawed mother's own milk when fresh HM was unavailable. Protein and fat analysis of the HM was done using mid-infrared spectroscopy (MilkoScan Minor ${ }^{\mathrm{TM}}$, Foss, Hillerød, Denmark). Lactose content of $\mathrm{HM}$ was not measured as it is the most stable nutrient in HM and assumed to be $6.8 \mathrm{~g} / 100 \mathrm{~mL}$ [20]. The nutritional composition of fortifier, formula, parenteral nutrition solution and lipid solutions composition was as provided by the respective manufacturer. Energy intake was calculated using the Atwater factors of 4, 4 and $9 \mathrm{kcal}$ per gram of protein, carbohydrate and fat, respectively. A direct breast feed was defined as any time an infant was put to the breast as noted in the fluid balance charts. No attempt was made to quantitate the amount of milk transfer during a breast feed. While it is acknowledged that nutritive sucking skills develop at different rates, [21] the volume of milk taken at a breast feed is minimal ( $<10 \mathrm{~mL}$, approximately $<5 \%$ of daily intake) before 34 weeks PMA [22]. We therefore considered direct breast feeds before 34 weeks PMA as non-nutritive and investigated the relationship between growth and direct breastfeeds after 34 weeks PMA and until discharge home or estimated due data (EDD).

\subsection{Anthropometry and Clinical Outcomes}

Measurements were taken by trained staff using techniques outlined in the World Health Organization Multicentre Growth Reference Study [23]. Weight was measured at the same time daily in Intensive Care, and twice weekly in Special care using calibrated electronic balance scales accurate to $5 \mathrm{~g}$. Length and head circumference were measured weekly to the nearest $1 \mathrm{~mm}$ using a recumbent length board (O'Leary; Ellard Instruments, Monroe, WA, USA) and paper tape respectively. Clinical outcomes were defined according to the Australian and New Zealand Neonatal Network [24] as follows: necrotising enterocolitis, Bell's stage II or higher; chronic lung disease (CLD), oxygen requirement at 36 weeks post menstrual age, late-onset sepsis, positive blood culture and clinical signs.

\subsection{Statistical Methods}

When a mother's milk was insufficient for analysis the mean of that individual mother's HM analyses was used to represent HM composition values for that week. Descriptive statistics are presented according to birth weight categories $(<1000 \mathrm{~g}, \geq 1000 \mathrm{~g})$. Dietary intakes were compared with current recommendations $[11,15,25]$. The recommended nutrient intake levels reported in Koletzko et 
al. [25] are specific for birth weights up to $1500 \mathrm{~g}$ and provide recommendations for both parenteral and enteral nutrition and so are used as a comparison, noting that the most recent consensus guidelines by a panel of experts, recommending 3.5 to $4.5 \mathrm{~g}$ protein $/ \mathrm{kg}$ [15] are encompassed within Koletzko. The relationship between direct breast feeding and growth was investigated using Spearman rank order correlation coefficient. A summary variable representing change in rate of weight gain after 34 weeks PMA for each individual infant was produced using linear regression $[26,27]$ and the following equation:

$$
\Delta \mathrm{m}=\mathrm{m}_{2}-\mathrm{m}_{1}
$$

where $\Delta \mathrm{m}=$ Change in rate of weight gain $\left(\mathrm{g} /\right.$ day), $\mathrm{m}_{1}=$ Rate of weight gain from 2 nd day of regained birth weight to 34 weeks PMA (g/day) and $\mathrm{m}_{2}=$ Rate of weight gain after and including 34 weeks PMA (g/day) until study end (discharge or EDD).

Thus a negative change in rate of weight gain represents a slower rate of growth after 34 weeks PMA. The analysis was repeated after stratification for birth weight category and chronic lung disease (as determined by oxygen requirement at 36 weeks PMA). Infants were separated into groups according to their mean number of daily breast feeds after 34 weeks PMA $(<1,1-2,2-3, \geq 3)$ for descriptive analysis of change in growth. All statistical analyses were conducted using IBM SPSS Statistics version 19 (SPSS, Chicago, IL, USA).

\section{Results}

\subsection{Participant Characteristics and Clinical Outcomes}

All 92 infants were followed to original study end and included in the present analysis. The characteristics of participating infants and their mothers are presented in Table 1 . The clinical and growth outcomes of infants are presented in Table 2. A greater proportion of infants born $<1000 \mathrm{~g}$ had chronic lung disease $(n=29(66 \%)$ versus $n=8(17 \%)$, confirmed necrotizing enterocolitis $(n=7(16 \%)$ versus $n=1(2 \%)$ and sepsis $(n=8(18 \%)$ versus $n=5(10 \%)$. Those infants born $<1000 \mathrm{~g}$ however, had a slightly faster rate of fractional weight gain, defined as weight gain as a proportion of body weight in $\mathrm{g} / \mathrm{kg} /$ day; (Mean, SD weight gain of 16.0, 1.5 versus 15.2, $2.1 \mathrm{~g} / \mathrm{kg} /$ day in $<1000 \mathrm{~g}$ and $\geq 1000 \mathrm{~g}$ birth weight, respectively) (Table 2).

Table 1. Clinical characteristics of participants.

\begin{tabular}{cccc}
\hline $\begin{array}{c}\text { Infants } \\
(\boldsymbol{n}=\mathbf{9 2})\end{array}$ & $\begin{array}{c}\text { Whole Cohort } \\
(\boldsymbol{n}=\mathbf{9 2})\end{array}$ & $\begin{array}{c}<\mathbf{1 0 0 0} \mathbf{g} \\
(\boldsymbol{n}=\mathbf{4 4})\end{array}$ & $\begin{array}{c}>\mathbf{1 0 0 0} \mathbf{g} \\
(\boldsymbol{n}=\mathbf{4 8})\end{array}$ \\
\hline Gestational age (weeks) & $28(26-29)$ & $26(25-28)$ & $29(28-29)$ \\
\hline Recruitment hospital & & & \\
Women's and Children's Hospital & $80(87)$ & $38(86)$ & $42(88)$ \\
Flinders Medical Centre & $12(13)$ & $6(14)$ & $6(13)$ \\
Male infants & $40(44)$ & $19(43)$ & $21(44)$ \\
\hline Birth anthropometry & & & \\
Weight (g) & 1036,301 & 788,156 & 1262,209 \\
Length (cm) & $35.7,3.5$ & $32.9,2.7^{*}$ & $38.1,1.9$ \\
Head circumference (cm) & $25.4,2.2$ & $23.8,1.8$ & $26.9,1.5$ \\
Caesarean section & $59(64)$ & $31(71)$ & $28(58)$ \\
Multiple births (number of infants) & $24(26)$ & $10(23)$ & $14,(29)$ \\
Mothers & $(n=80)$ & $(n=39)$ & $(n=41)$ \\
\hline Age (years) & $30.2,5.8$ & $30.7,6.2$ & $29.1,5.2$ \\
Smoked during pregnancy & $15(19)$ & $8(21)$ & $7(17)$ \\
Previous preterm birth & $11(14)$ & $1(3)$ & $10(24)$ \\
Received antenatal steroids & $71(89)$ & $35(90)$ & $36(88)$ \\
Received IVF & $11(14)$ & $4(10)$ & $7(17)$ \\
Completed Secondary Education ${ }^{\dagger}$ & $57(72)$ & $30(77)$ & $27(66)$ \\
\hline
\end{tabular}

Data are presented as median (interquartile range), $n(\%)$, Mean, SD. ${ }^{*} n=43$ infants; $^{\dagger} n=79$ mothers; Abbreviations: IVF, in vitro fertilisation. 
Table 2. Infant outcomes.

\begin{tabular}{|c|c|c|c|}
\hline Clinical Outcomes & $\begin{array}{l}\text { Whole Cohort } \\
\quad(n=92)\end{array}$ & $\begin{array}{l}<1000 \mathrm{~g} \\
(n=44)\end{array}$ & $\begin{array}{l}\geq 1000 \mathrm{~g} \\
(n=48)\end{array}$ \\
\hline Chronic lung disease $^{+}$ & $37(40)$ & $29(66)$ & $8(17)$ \\
\hline Received corticosteroid treatment & $31(34)$ & $23(53)$ & $8(17)$ \\
\hline Confirmed necrotizing enterocolitis & $8(9)$ & $7(16)$ & $1(2)$ \\
\hline Intraventricular haemorrhage $\ddagger$ & $19(21)$ & $9(21)$ & $10(21)$ \\
\hline Sepsis & $13(14)$ & $8(18)$ & $5(10)$ \\
\hline Nasal CPAP & $26(28)$ & $9(21)$ & $17(35)$ \\
\hline Length of stay $\S$ & $75.1,18.6$ & $87.1,13.8$ & $64.2,15.4$ \\
\hline Post-menstrual age at discharge or EDD (weeks) & $38(37-40)$ & $39(38-40)$ & $37(37-39)$ \\
\hline \multicolumn{4}{|l|}{ Growth outcomes } \\
\hline Days to regain birth weight, mean (SD) & $11.2,3.9$ & $11.3,4.3$ & $11.0,3.5$ \\
\hline Weight gain $(\mathrm{g} /$ day $) *$ & $27.4,5.7$ & $25.0,4.7$ & $29.6,5.8$ \\
\hline Intrauterine weight gain (g/kg/day) [28] & 15.0 & & \\
\hline Weight gain $(\mathrm{g} / \mathrm{kg} /$ day $)$ & $15.6,1.8$ & $16.0,1.5$ & $15.2,2.1$ \\
\hline Weight gain before 34 weeks PMA (g/day) & $24.6,7.3$ & $21.2,6.1$ & $27.6,7.0$ \\
\hline Weight gain after 34 weeks PMA (g/day) & $30.2,6.5$ & $29.5,5.4$ & $30.9,7.4$ \\
\hline Length gain $(\mathrm{cm} /$ week) & $1.0,0.1$ & $1.0,0.1$ & $1.0,0.2$ \\
\hline Head circumference gain (cm/week) & $0.9,0.1$ & $0.9,0.1$ & $0.9,0.2$ \\
\hline Discharge weight $(\mathrm{g})$ & 2697,357 & 2662,428 & 2729,276 \\
\hline \multicolumn{4}{|l|}{ Dietary Outcomes } \\
\hline Age study fortifier commenced (days) & $13(10-18)$ & $15(12-19)$ & $11(8-14)$ \\
\hline Age enteral feeds commenced (days) & $3(2,4)$ & $4(3,5)$ & $3(2,4)$ \\
\hline Days to reach full enteral feeds (days) & $15(12-21)$ & $19(14-26)$ & $13(10-7)$ \\
\hline HMF introduced (mL/kg enteral intake) & $118.9,35.6$ & $109.7,38.1$ & $126.9,31.3$ \\
\hline Days on parenteral nutrition (days) & $16(11-25)$ & $23(16-30)$ & $12(8-7)$ \\
\hline Days on intravenous lipid (days) & $11(7-16)$ & $16(10-23)$ & $9(5-12)$ \\
\hline \multicolumn{4}{|l|}{ Proportion of energy from parenteral nutrition (percentage) } \\
\hline Week 1 & $95(82-100)$ & $98(90-100)$ & $92(72-100)$ \\
\hline Week 2 & $48(2-80)$ & $63(37-87)$ & $21(0-70)$ \\
\hline \multicolumn{4}{|l|}{$\begin{array}{l}\text { Human milk as a proportion of measured enteral intake } \\
\text { (number of infants) }\end{array}$} \\
\hline$>80 \%$ & $56(61)$ & $25(57)$ & $31(65)$ \\
\hline $20 \%$ to $80 \%$ & $29(32)$ & $15(34)$ & $14(29)$ \\
\hline$<20 \%$ & $7(8)$ & $4(9)$ & $3(6)$ \\
\hline
\end{tabular}

Data are presented as $n(\%)$, Mean, SD and median (interquartile range). Abbreviations: CPAP, continuous positive airway pressure; $\mathrm{EDD}$, estimated due date; $\mathrm{HMF}$, human milk fortifier; ${ }^{\dagger}$ As defined by requirement for supplemental oxygen at 36 weeks post-menstrual age; ${ }^{\ddagger} n=91$ infants; ${ }^{\S}$ To discharge home or estimated due date, whichever came first; * Weight gain from when birth weight regained and maintained 2 days.

\subsection{Nutritional Management}

The randomised trial [19] analysis showed that nutritional management of the infants did not differ between groups except for protein intakes, we therefore present protein intake by birth weight $(<1000 \mathrm{~g}$ and $\geq 1000 \mathrm{~g})$ and by randomised group. Median daily volume and energy intakes between the randomised groups were not different [19] and are therefore presented according to birth weight category $(<1000 \mathrm{~g}$ and $\geq 1000 \mathrm{~g}$ ). Infants born $<1000 \mathrm{~g}$ took longer to commence (Median (IQR) of $4(3,5)$ versus $3,(2,4)$ days) and reach full enteral feeds (Median (IQR) of $19(14,26)$ versus $13(10,17)$ days), and received parenteral nutrition for longer (Median (IQR) of $23(16,30)$ versus $12(8,17)$ days) than infants born weighing $\geq 1000 \mathrm{~g}$ (Table 2). First week protein intakes did not reach recommendations regardless of birth weight category or to which protein fortifier group the infants were randomised (Table 3). Overall, infants born $<1000 \mathrm{~g}$ were underfed protein, regardless of protein fortifier group, while those born $\geq 1000 \mathrm{~g}$ met recommendations (Table 3). 
Table 3. Days 0-3 and weekly intakes of energy, protein and fluid compared with recommendations.

\begin{tabular}{|c|c|c|c|c|}
\hline & \multirow{2}{*}{$\begin{array}{c}\text { Energy Intake } \\
\text { (kcal/kg/day) }\end{array}$} & \multicolumn{2}{|c|}{ Protein Intake (g/kg/day) } & \multirow{2}{*}{$\begin{array}{c}\text { Fluid Intake }{ }^{\dagger} \\
\text { (mL/kg/day) }\end{array}$} \\
\hline & & Std. Protein & High Protein & \\
\hline \multicolumn{5}{|l|}{$<1000 \mathrm{~g}(n=44)$} \\
\hline Recommendation: Day 0 parenteral RNI [25] & $60-80$ & \multicolumn{2}{|c|}{$\geq 2 *$} & $90-120$ \\
\hline Day 0 & $8(5,13)$ & $0.2(0.1-0.3)$ & $0.3(0.0-0.5)$ & $16(10-28)$ \\
\hline Recommendation: Transition combined $\ddagger[25]$ & $80-100$ & \multicolumn{2}{|c|}{$\geq 3.5^{*}$} & \\
\hline Day 1 & $27(24,35)$ & $0.8(0.6-0.9)$ & $0.8(0.5-1.2)$ & $58(49-76)$ \\
\hline Day 2 & $44(35,53)$ & $1.0(0.7-1.4)$ & $1.4(1.0-1.7)$ & $85(75-105)$ \\
\hline Day 3 & $54(47,63)$ & $1.6(1.4-2.0)$ & $2.0(1.2-2.3)$ & $111(97-130)$ \\
\hline Recommendation: Combined intake $\ddagger[11]$ & $110-130$ & $4.0-4.5$ & & $135-200$ \\
\hline Week $2 \S$ & $97(76-116)$ & $3.0(2.0-3.7)$ & $2.8(2.3-3.5)$ & $152(124-172)$ \\
\hline Week 3 & $119(91-142)$ & $3.6(2.6-4.1)$ & $3.7(2.7-4.6)$ & $161(142-170)$ \\
\hline Week 4 & $137(121-151)$ & $3.6(3.3-3.9)$ & $4.3(3.8-4.7)$ & $165(152-172)$ \\
\hline \multicolumn{5}{|l|}{$\geq 1000 \mathrm{~g}(n=48)$} \\
\hline Recommendation: Day 0 parenteral RNI [25] & $60-80$ & \multicolumn{2}{|c|}{$\geq 2 *$} & $70-90$ \\
\hline Day 0 & $8(5-15)$ & $0.3(0.2-0.4)$ & $0.3(0.0-0.4)$ & $19(11-34)$ \\
\hline Recommendation: Transition combined $\ddagger[25]$ & $80-100$ & \multicolumn{2}{|c|}{$\geq 3.5 *$} & \\
\hline Day 1 & $29(24-35)$ & $0.8(0.4-1.1)$ & $1.0(0.8-1.2)$ & $62(51-70)$ \\
\hline Day 2 & $44(34-53)$ & $1.4(0.8-1.9)$ & $1.3(1.1-1.7)$ & $85(66-99)$ \\
\hline Day 3 & $65(47-72)$ & $2.2(1.3-2.8)$ & $2.0(1.5-2.5)$ & $115(87-127)$ \\
\hline Recommendation: Enteral intake $\ddagger[25]$ & $110-130$ & $3.5-4.5$ & & $135-200$ \\
\hline Week $2 \S$ & $120(96-138)$ & $3.7(3.0-4.0)$ & $4.3(2.8-4.8)$ & $164(149-172)$ \\
\hline Week 3 & 135 (118-147) & $3.8(3.4-4.1)$ & $4.4(4.0-4.8)$ & $162(153-172)$ \\
\hline Week 4 & 137 (124-151) & $3.8(3.5-4.1)$ & $4.1(3.6-4.5)$ & 164 (151-172) \\
\hline
\end{tabular}

Data are presented as median (interquartile range); Recommended intakes are in italics. ${ }^{*}$ amino acid requirement in $\mathrm{g}$ of protein equivalent; ${ }^{\dagger}$ Includes nutritional fluids only; ${ }^{\ddagger}$ Intakes are presented as combined enteral and parenteral intakes as while parenteral intakes are titrated down, enteral intakes are correspondingly incrementally increased on an individual basis; $§$ Study fortifier was begun at median 13 days of age (week of life 2-3) Abbreviations: RNI, recommended nutrient intake.

\subsection{Direct Breast Feeding and Growth}

A moderate, negative correlation between the mean number of direct breast feeds and change in rate of weight gain after 34 weeks PMA $(r=-0.37, p=0.001)$ was found. Thus, the higher the number of direct breast feeds per day, the more the growth rate slowed after 34 weeks. This was more pronounced in infants born weighing $\geq 1000 \mathrm{~g}(r=-0.40, p=0.005)$ and less so in infants born $<1000 \mathrm{~g}(r=-0.24, p=0.11)$. This was also the case in infants without chronic lung disease $(r=-0.37$, $p=0.005)$, compared with infants with chronic lung diseases $(r=-0.20, p=0.24)$. The characteristics of the groups according to the number of daily breastfeeds after 34 weeks are presented in Tables S1 and S2. Within each group, there were a similar number of infants allocated to protein fortifier groups. There were no infants with chronic lung disease or born $<28$ weeks' GA in the breastfeed group with $>3$ breastfeeds/day. The lowest breastfeed group ( $<1$ breastfeed/day) had a much lower proportion of their enteral intake as human milk, indicating that they consumed more preterm formula.

The rate of weight gain for infants with a mean number of breastfeeds $<1$ per day after 34 weeks PMA increased by an average of 8.0 (SD 8.8) g/day (Figure 1), while infants with mean $>3$ breast feeds per day displayed faltering growth after 34 weeks PMA (mean change in rate of weight gain $-4.6 \mathrm{~g} /$ day, SD $9.4 \mathrm{~g} /$ day). 


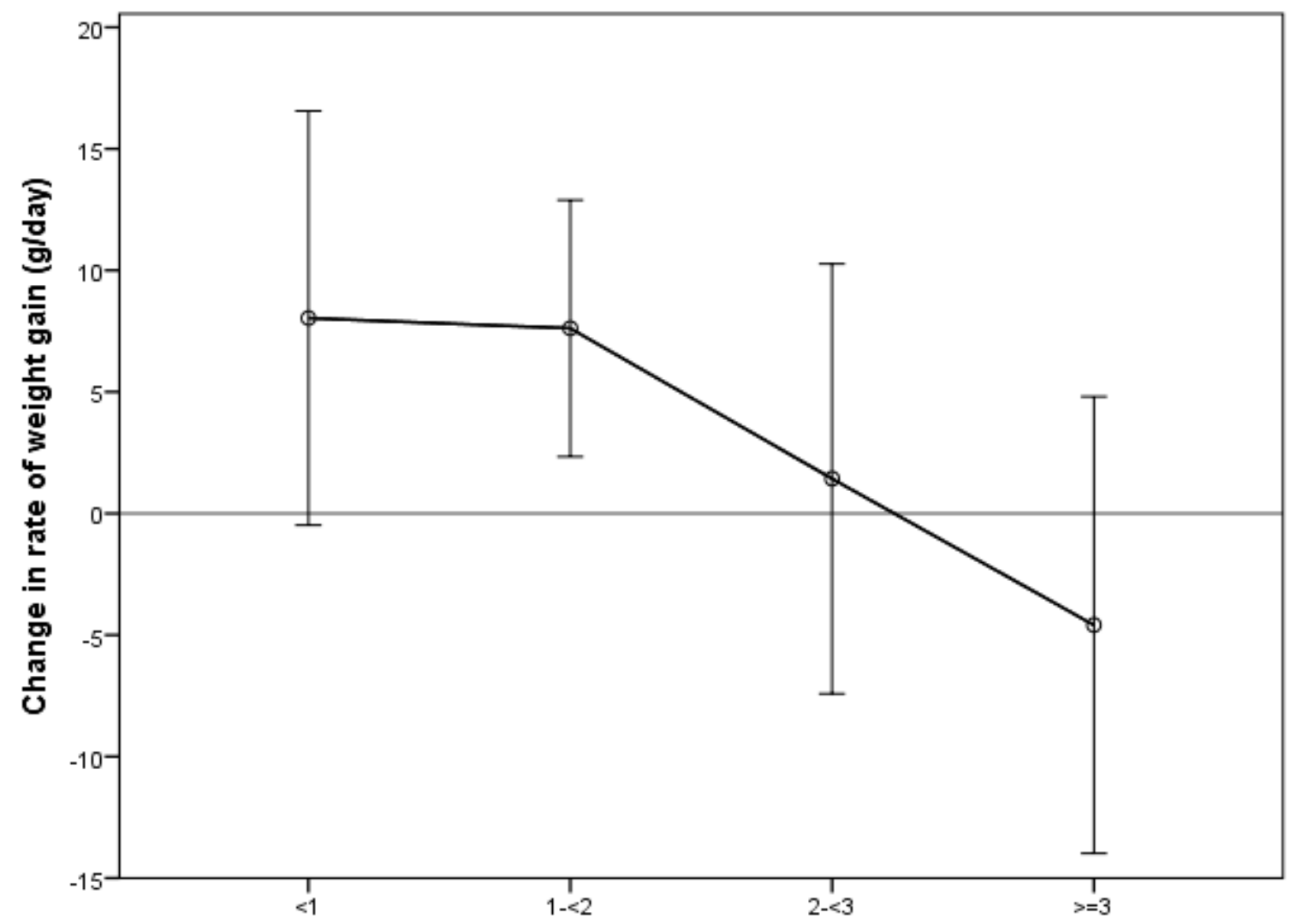

Figure 1. Mean change in rate of weight gain after 34 weeks for infants having $<1,1-<2,2-<3$ and $\geq 3$ breast feeds per day. Markers represent mean for group, bars represent 1 standard deviation from mean. Solid line at zero indicates no change in rate of weight gain between growth periods.

\section{Discussion}

In this study of infants born at $<31$ weeks gestation we found infants born $\geq 1000 \mathrm{~g}$ achieved protein intakes within recommendations and adequate energy intakes after the first week of life, while infants born $<1000 \mathrm{~g}$ received insufficient protein, regardless of which protein fortifier they were allocated, and did not reach recommended energy intakes until week 3 . Infants born $<1000 \mathrm{~g}$ typically present the most complexity with regard to metabolic balance when feeding, thus it is not surprising they were underfed protein. This finding is also consistent with other studies showing inadequate protein intakes in these infants, particularly in the first weeks of life $[7,8,10,29,30]$. There is conflicting evidence regarding energy intakes however, with some studies showing recommendations are typically met $[7,8]$ and others showing inadequate energy intakes consistent with our finding $[10,29,30]$. All infants were underfed protein and energy in the first days of life, with intakes barely reaching half the recommended intake by the third day of life. With studies showing protein intakes during this period to be an important predictor of growth [31,32] it is perhaps no surprise these infants only just reached intrauterine growth rates [28]. The long term implications of such intakes are also concerning, with first week protein intakes suggested to be predictive of neurodevelopmental outcome at 18 months [33]. A more aggressive approach to both parenteral and early enteral feeding may therefore be required.

In this exploratory analysis we have shown that the rate of weight gain slows as the number of daily breastfeeds increases. The group of infants having the highest number of direct breast feeds each day slowed their rate of weight gain by $4.6 \mathrm{~g} /$ day after the introduction of direct breast feeds. This is in contrast to those infants with $<1$ and $1-2$ breast feeds per day, whose rate of growth increased by 8 and $7.6 \mathrm{~g} /$ day respectively. Growth rates increase after 34 weeks PMA as infants are generally 
more clinically stable and experience fewer interruptions to feeding. Growth percentile data for Australian preterm infants reported by Beeby et al. [34] when calculated in the same manner as in the present study, indicate an increased rate of growth of $3.9 \mathrm{~g} /$ day after 34 weeks as compared to before. Extrapolating the present results to a difference in weight at estimated due date, infants with the highest number of direct breast feeds would weigh $\sim 190 \mathrm{~g}$ more if they maintained their previous rate of growth, and $\sim 530 \mathrm{~g}$ more if they increased their rate of growth in the same manner as the infants with the lowest number of direct breast feeds. Of note however, the number of infants with mean $>3$ direct breast feeds per day was small $(n=9)$, and the majority of these infants were born $\geq 1000 \mathrm{~g}$, which may explain the result found after stratification by birth weight category, as there may not be enough infants born $<1000 \mathrm{~g}$ taking frequent direct breast feeds to examine the relationship in this group alone. Nonetheless, the clinical significance of this effect is substantial and warrants further, dedicated research to confirm the effect found in this small exploratory analysis.

There are a number of possible explanations for the faltering growth seen with increasing number of direct breast feeds and the cause is likely to be multifactorial. Firstly, the infants' ability to self-regulate may not be developed sufficiently to increase the volume of intake and compensate for the lower caloric density of a breastfeed. Secondly, the infants with the lowest number of breastfeeds were those consuming more preterm formula, with a higher protein and energy content than human milk. Finally, it's possible that the infants did not receive sufficient fat rich hind milk. Regardless of the reason, the slowed weight gain is of clinical concern. The psychological and attachment benefits of direct breast feeding for mother and infant are well documented [12,35]. It has also been shown that earlier initiation of, and therefore longer experience and practice with direct breast feeding results in earlier establishment of full breast feeding [22,36,37]. The achievement of sucking feeds is a crucial factor influencing readiness for discharge home in preterm infants [16,22]. Thus while frequent direct breast feeding appears to facilitate many desirable outcomes for preterm infants and their families [12] it may also compromise the goal of achieving optimal nutrient intake and growth during admission. Strategies to improve growth may include test weighing of breastfeeds to determine the volume taken more accurately, simply being mindful to not overestimate the volume taken or providing fortifier as a separate, concentrated solution before or after a direct breast feed. Infants may then gain the benefit of both early direct breast feeding and HM fortification, rather than have these as competing interests. These strategies may result in the preservation of the earlier growth rate and therefore better growth outcomes at discharge and warrants further investigation.

The small number of infants taking a large number of direct breast feeds toward study end limited statistical analysis and thus strength of conclusions drawn from this study. That there were few infants born $<1000 \mathrm{~g}$ having frequent direct breast feeds compared with infants born $\geq 1000 \mathrm{~g}$ additionally complicates interpretation of these results. However, the regular measurement of HM composition is a major strength of our study compared with many other studies which simply assume values of HM composition. The inclusion of infants with morbidities typical of infants born at $<31$ weeks gestation [38] ensures generalisability of the study to all infants treated in Australian neonatal intensive care units. Additionally, the pragmatic approach to feeding is reflective of Australian clinical practice, thus these results are highly relevant to the clinical setting.

\section{Conclusions}

Protein intakes of infants with birth weight $<1000 \mathrm{~g}$ did not meet recommendations and all infants were underfed protein and energy in the first week of life. Greater attention to protein and energy intakes in the first week of life, and throughout the neonatal admission for the smallest babies i.e., those born $<1000 \mathrm{~g}$, deserve consideration. Faltering rate of weight gain was shown to be correlated with increasing number of direct breast feeds, and this warrants further research to confirm this observed effect. 
Supplementary Materials: The following are available online at http:/ /www.mdpi.com/1660-4601/15/6/1196/ s1, Table S1: Clinical characteristics of participants by randomisation group, Table S2: Infant outcomes by randomisation group.

Author Contributions: E.T. contributed to the conception of the secondary analyses; analysed and interpreted the data; drafted the manuscript; approved the final version to be published and agrees to be accountable for all aspects of the work; J.M. contributed to the conception of the secondary analyses; conducted and analysed the original RCT; contributed to drafts of the manuscript; approved the final version to be published and agrees to be accountable for all aspects of the work; M.M. conceptualised the original RCT; contributed to the analysis and interpretation of both the original RCT and the secondary analysis; read and commented on draft manuscripts; approved the final version to be published and agrees to be accountable for all aspects of the work; A.J.M. contributed to the conception and data collection of the original RCT; read and commented on draft manuscripts; approved the final version to be published and agrees to be accountable for all aspects of the work; S.A.M. contributed to the conception and data collection of the original RCT; read and commented on draft manuscripts; approved the final version to be published and agrees to be accountable for all aspects of the work; R.A.G. conceptualised the original RCT; contributed to the analysis and interpretation of both the original RCT and the secondary analysis; read and commented on draft manuscripts; approved the final version to be published and agrees to be accountable for all aspects of the work; C.T.C. contributed to the conception, analysis and interpretation of both the original RCT and the secondary analysis; read and commented on draft manuscripts; approved the final version to be published and agrees to be accountable for all aspects of the work.

Acknowledgments: The original study was supported by a Grant-in-Aid from Denis Harwood, and the current study was supported by the Women's and Children's Health Research Institute. The trial human milk fortifiers for the original study were made and donated by Nestle Product Technology Centre, Konolfingen, Switzerland. Doctoral scholarships were provided by The University of Adelaide (JM) and the Women's and Children's Hospital Foundation MS McLeod Research Fund (JM). Research fellowships were provided by the National Health and Medical Research Council of Australia (MM Principal Research Fellow APP1061704 and RAG Senior Principal Research Fellow APP1046207), The University of Adelaide, Faculty of Health Sciences, Early Career Research Fellowship (CTC) and the MS McLeod Postdoctoral Research Fellowship, MS McLeod Research Fund, Women's and Children's Hospital Research Foundation (CTC). The contents of the published material are solely the responsibility of the authors and do not reflect the views of the National Health and Medical Research Council of Australia.

Conflicts of Interest: C.T.C., R.A.G. and M.M. have received non-financial support from Clover Corporation, Mead Johnson and Nestle Nutrition for research outside that of the submitted work. R.A.G. serves on a scientific advisory board for Fonterra; M.M. serves on scientific advisory boards for Nestle, Fonterra and Nutricia. Associated honoraria for R.A.G. and M.M. are paid to their respective institutions to support conference travel and continuing education for post graduate students and early career researchers. The other authors declare no conflict of interest.

\section{References}

1. De Curtis, M.; Rigo, J. The nutrition of preterm infants. Early Hum. Dev. 2012, 88, S5-S7. [CrossRef] [PubMed]

2. Belfort, M.B.; Rifas-Shiman, S.L.; Sullivan, T.; Collins, C.T.; McPhee, A.J.; Ryan, P.; Kleinman, K.P.; Gillman, M.W.; Gibson, R.A.; Makrides, M. Infant growth before and after term: Effects on neurodevelopment in preterm infants. Pediatrics 2011, 128, E899-E906. [CrossRef] [PubMed]

3. Ehrenkranz, R.A.; Dusick, A.M.; Poole, W.K.; Vohr, B.R.; Wrage, L.A.; Wright, L.L. Growth in the neonatal intensive care unit influences neurodevelopmental and growth outcomes of extremely low birth weight infants. Pediatrics 2006, 117, 1253-1261. [CrossRef] [PubMed]

4. Lechner, B.E.; Vohr, B.R. Neurodevelopmental outcomes of preterm infants fed human milk: A systematic review. Clin. Perinatol. 2017, 44, 69-83. [CrossRef] [PubMed]

5. Schanler, R.J.; Atkinson, S.A. Effects of nutrients in human milk on the recipient premature infant. J. Mammary Gland Biol. Neoplasia 1999, 4, 297-307. [CrossRef] [PubMed]

6. Hay, W.W.; Thureen, P. Protein for preterm infants: How much is needed? How much is enough? How much is too much? Pediatr. Neonatol. 2010, 51, 198-207. [CrossRef]

7. Cormack, B.E.; Bloomfield, F.H. Audit of feeding practices in babies $<1200 \mathrm{~g}$ or 30 weeks gestation during the first month of life. J. Paediatr. Child Health 2006, 42, 458-463.

8. Arslanoglu, S.; Moro, G.E.; Ziegler, E.E. Preterm infants fed fortified human milk receive less protein than they need. J. Perinatol. 2009, 29, 489-492. [CrossRef] [PubMed]

9. McLeod, G.; Sherriff, J.; Nathan, E.; Hartmann, P.E.; Simmer, K. Four-week nutritional audit of preterm infants born <33 weeks gestation. J. Paediatr. Child Health 2013, 49, E332-E339. [PubMed] 
10. Embleton, N.E.; Pang, N.; Cooke, R.J. Postnatal malnutrition and growth retardation: An inevitable consequence of current recommendations in preterm infants? Pediatrics 2001, 107, 270-273. [CrossRef] [PubMed]

11. Agostoni, C.; Buonocore, G.; Carnielli, V.P.; De Curtis, M.; Darmaun, D.; Decsi, T.; Domellof, M.; Embleton, N.D.; Fusch, C.; Genzel-Boroviczeny, O.; et al. Enteral nutrient supply for preterm infants: Commentary from the european society for paediatric gastroenterology, hepatology, and nutrition committee on nutrition. J. Pediatr. Gastroenterol. Nutr. 2010, 50, 85-91. [CrossRef] [PubMed]

12. Buckley, K.M.; Charles, G.E. Benefits and challenges of transitioning preterm infants to at-breast feedings. Int. Breastfeed. J. 2006, 1, 13. [CrossRef] [PubMed]

13. Kuschel, C.A.; Harding, J.E. Protein supplementation of human milk for promoting growth in preterm infants. Cochrane Database Syst. Rev. 2000. [CrossRef] [PubMed]

14. Arslanoglu, S.; Moro, G.E.; Ziegler, E.E.; Nutr, W.W.G. Optimization of human milk fortification for preterm infants: New concepts and recommendations. J. Perinat. Med. 2010, 38, 233-238. [CrossRef] [PubMed]

15. Kumar, R.K.; Singhal, A.; Vaidya, U.; Banerjee, S.; Anwar, F.; Rao, S. Optimizing nutrition in preterm low birth weight infants-consensus summary. Front. Nutr. 2017, 4, 20. [CrossRef] [PubMed]

16. Lemons, J.A.; Blackmon, L.R.; Fanaroff, A.A.; MacDonald, H.M.; Miller, C.A.; Papile, L.A.; Rosenfeld, W.; Shoemaker, C.T.; Speer, M.E.; Comm Fetus, N. Hospital discharge of the high-risk neonate-proposed guidelines. Pediatrics 1998, 102, 411-417.

17. Teller, I.C.; Embleton, N.D.; Griffin, I.J.; van Elburg, R.M. Post-discharge formula feeding in preterm infants: A systematic review mapping evidence about the role of macronutrient enrichment. Clin. Nutr. 2016, 35, 791-801. [CrossRef] [PubMed]

18. McCormick, F.M.; Tosh, K.; McGuire, W. Ad libitum or demand/semi-demand feeding versus scheduled interval feeding for preterm infants. Cochrane Database Syst. Rev. 2010, CD005255. [CrossRef]

19. Miller, J.; Makrides, M.; Gibson, R.A.; McPhee, A.J.; Stanford, T.E.; Morris, S.; Ryan, P.; Collins, C.T. Effect of increasing protein content of human milk fortifier on growth in preterm infants born at $<31$ wk gestation: A randomized controlled trial. Am. J. Clin. Nutr. 2012, 95, 648-655. [PubMed]

20. Newberg, D.; Neubauer, S. Carbohyrdates in milks: Analyis quantities and significance. In Handbook of Milk Composition; Jensen, R., Ed.; Academic Press: San Diego, CA, USA, 1995; pp. 273-350.

21. Dodrill, P.; Donovan, T.; Cleghorn, G.; McMahon, S.; Davies, P.S. Attainment of early feeding milestones in preterm neonates. J. Perinatol. 2008, 28, 549-555. [CrossRef] [PubMed]

22. Cunha, M.; Barreiros, J.; Goncalves, I.; Figueiredo, H. Nutritive sucking pattern-from very low birth weight preterm to term newborn. Early Hum. Dev. 2009, 85, 125-130. [CrossRef] [PubMed]

23. World Health Organisation. Who Child Growth Standards, Training Course on Child Growth Assessment. Available online: http:/ / www.who.int/childgrowth/training/en/ (accessed on 12 July 2017).

24. Abeywardana, S. The Report of the Australian and New Zealand Neo-Natal Network, 2004; ANZNN: Sydney, Australia, 2006.

25. Koletzko, B.; Poindexter, B.; Uauy, R. Nutritional Care of Preterm Infants Scientific Basis and Practical Guidelines. Indian J. Med. Res. 2016, 143, 531-532.

26. Matthews, J.N.S.; Altman, D.G.; Campbell, M.J.; Royston, P. Analysis of serial measurements in medical research. BMJ 1990, 300, 230-235. [CrossRef] [PubMed]

27. Patel, A.L.; Engstrom, J.L.; Meier, P.P.; Kimura, R.E. Accuracy of methods for calculating postnatal growth velocity for extremely low birth weight infants. Pediatrics 2005, 116, 1466-1473. [CrossRef] [PubMed]

28. Sparks, J.W. Human intrauterine growth and nutrient accretion. Semin. Perinatol. 1984, 8, 74-93. [PubMed]

29. Loui, A.; Tsalikaki, E.; Maier, K.; Walch, E.; Kamarianakis, Y.; Obladen, M. Growth in high risk infants $<1500$ g birthweight during the first 5 weeks. Early Hum. Dev. 2008, 84, 645-650. [PubMed]

30. Olsen, I.E.; Richardson, D.K.; Schmid, C.H.; Ausman, L.M.; Dwyer, J.T. Intersite differences in weight growth velocity of extremely premature infants. Pediatrics 2002, 110, 1125-1132. [CrossRef] [PubMed]

31. Senterre, T.; Rigo, J. Optimizing early nutritional support based on recent recommendations in vlbw infants and postnatal growth restriction. J. Pediatr. Gastroenterol. Nutr. 2011, 53, 536-542. [CrossRef] [PubMed]

32. Senterre, T.; Rigo, J. Reduction in postnatal cumulative nutritional deficit and improvement of growth in extremely preterm infants. Acta Paediatr. 2012, 101, E64-E70. [CrossRef] [PubMed] 
33. Stephens, B.E.; Walden, R.V.; Gargus, R.A.; Tucker, R.; McKinley, L.; Mance, M.; Nye, J.; Vohr, B.R. First-week protein and energy intakes are associated with 18-month developmental outcomes in extremely low birth weight infants. Pediatrics 2009, 123, 1337-1343. [CrossRef] [PubMed]

34. Beeby, P.J.; Bhutap, T.; Taylor, L.K. New south wales population-based birthweight percentile charts. J. Paediatr. Child Health 1996, 32, 512-518. [CrossRef] [PubMed]

35. Mezzacappa, E.S.; Katkin, E.S. Breast-feeding is associated with reduced perceived stress and negative mood in mothers. Health Psychol. 2002, 21, 187-193. [CrossRef] [PubMed]

36. Nyqvist, K.H. Early attainment of breastfeeding competence in very preterm infants. Acta Paediatr. 2008, 97, 776-781. [CrossRef] [PubMed]

37. Pickler, R.H.; Best, A.; Crosson, D. The effect of feeding experience on clinical outcomes in preterm infants. J. Perinatol. 2009, 29, 124-129. [CrossRef] [PubMed]

38. Australian and New Zealand Neonatal Network. Report of the Australian and New Zealand Neonatal Network 2006; Australian and New Zealand Neonatal Network: Sydney, Australia, 2009.

(C) 2018 by the authors. Licensee MDPI, Basel, Switzerland. This article is an open access article distributed under the terms and conditions of the Creative Commons Attribution (CC BY) license (http://creativecommons.org/licenses/by/4.0/). 